\title{
THE JUST SHALL LIVE BY FAITH.
}

By Professor George B. Stevens, Ph.D., D.D., Yale University, New Haven, Conn.

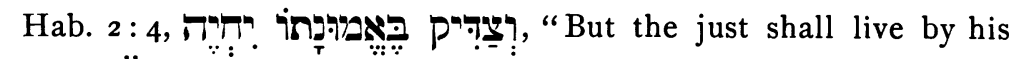
constancy."

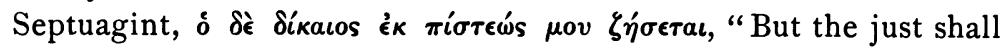
live by my faith" (Alexandrian text, "But my just one shall live by faith").

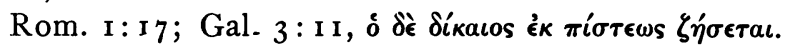

A. V.: "The just shall live by faith."

R. V.: "But the righteous shall live by faith."

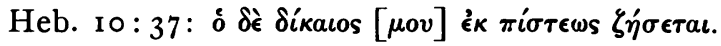

A. V.: "Now the just shall live by faith."

R. V.: "But my righteous one shall live by faith."

THE object of this article is to exhibit the original connection of this celebrated "evangelical text," to show how, through the Septuagint translation, its New Testament application was made easy and natural, and to inquire what principles of interpretation its quotation and use illustrate.

Habakkuk's prophecy has principal reference to a prospective Chaldean invasion (probably about 605 B. C.). The prophecy is dramatic in form; it is constructed on the plan of a dialogue between the prophet and Jehovah. The seer first raises a bitter cry over the lawless violence which prevails in the land $(1: 2-4)$. Jehovah answers: The punishment for this is at hand. The Chaldeans, "that bitter and hasty nation, which march through the breadth of the earth, to possess dwelling-places that are not theirs" ( $I: 6)$, will soon sweep like a storm over Judah, spreading desolation far and wide (I: 5-II). This reply gives rise to a new perplexity: Will Jehovah, then, permit these rapacious idolaters to overwhelm the whole people, destroying innocent and guilty alike? Will he hold his peace "when the wicked swalloweth up the man that is more righteous than he" (I: I 2-I 7)? 
The prophet now ascends (in imagination) his watch-tower and awaits an answer to his "complaint" against this impending injustice (2:I). The oracle speaks: Write down the vision and make it plain; it hastens to its fulfilment; the Chaldean is proud (and his pride shall prove his undoing), "but the just, by his steadfastness, shall be preserved alive" (2:4). In the remainder of the chapter the haughtiness and rapacity of the enemy are described, and a series of woes denounced against him. Chap. 3 is a lyric ode celebrating Jehovah's own appearance in judgment upon the heathen and for the salvation of his people.

This sketch makes evident the general import of the text in question. "Shall live" means "shall escape destruction by the enemy," "shall be preserved alive." The word rendered "faith" (Emunah) in our English versions means "faithfulness, steadfastness, constancy." Elsewhere it is used to denote "fidelity, equity, truth, and sincerity" (Hos. 2:20; Prov. $14: 5 ; 12: 17,22$ ). It is applied to the trustworthiness of God: "A God of faithfulness and without iniquity, just and right is he" (Deut. 32:4).

Now the Septuagint rendered Emunah and its corresponding adjective by $\pi i \sigma \tau \iota s$ and $\pi \iota \sigma \tau o$ 's ("faith" and "faithful") - words which naturally express the two related, but distinguishable, ideas which we designate by the terms "fidelity" and "trust." I should not say, with Dr. George Adam Smith," that the Septuagint "wrongly translated" Emunah by $\pi i \sigma \tau \iota s$, but rather that the term $\pi i \sigma \tau \iota s$, being a word of broader and more varied significance than Emunah in Hebrew, would easily make the passage capable of a wider application than the Old Testament original suggests. We may say further that, if the original setting of the verse should be disregarded and the term "shall live" be taken in a spiritual, instead of its original literal, meaning, the way would be opened to quite a new application of the passage. We shall see that this was precisely what happened.

The author of the epistle to the Hebrews employed the text in question in a sense closely resembling the original, though he applied it to an entirely new subject. He quotes from the

I Book of the Truelve Prophets, Vol. II, p. I40. 
Septuagint vss. 3 and 4 , reproducing the Greek variations from the meaning of the original. The principal variations are: (I) The phrase "For yet a very little while," by which the "coming" which is announced is pictured as more immediate, has nothing corresponding to it in the LXX. It may be an elaboration of the idea of haste involved in the passage as a whole, or may be derived from prophetic language elsewhere used (e.g., Isa. 26:20). (2) A change of subject by which "It (the vision) shall surely come," becomes "He (God) shall surely come," etc. (3) The adoption of the Septuagint's entire misunderstanding of the first part of vs. 4 so that the original, "Behold, puffed up within him is his soul, it is not upright," is transformed into "If he shrink back, my soul has no pleasure in him." (4) In quoting vs. 4 the author transposes the two parts of the verse, so as to give an order the reverse of that in the Septuagint, thus: "My just one shall live," etc., "and if he shrink back," etc. (5) According to the best authenticated text of Hebrews, the author has quoted the passage in its (quite unsupported) Alexandrian form : "My just one shall live by faith." This is natural in view of his Alexandrian training.

Here the whole passage is used as an assurance and description of the speedy coming of the Messiah to judgment. The readers are enduring "a great conflict of sufferings," but they are proving themselves brave and steadfast under their trials. The author exhorts them to courage and confidence, for soon the coming One (the Messiah) will appear, and he who has been constant shall be saved on account of his fidelity, whereas the weak and vacillating shall be rejected in the messianic judgment. It will be noted that $\pi i \sigma \tau \iota s$ here is practically synonymous with

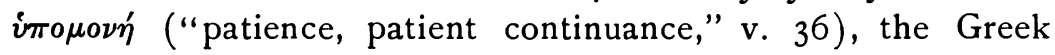
word which, I should think, was the nearest possible equivalent of the Hebrew Emunah. We note here, then, three things: (I) the great freedom used in dealing with the form of the passage; (2) the application of the two verses as a whole to a subject to which the original has no reference-in the Old Testament the prospect of a Chaldean invasion; here, the second coming of Christ; and (3) the close similarity of the sense borne by the 
words under immediate consideration to that of the original; in both cases salvation is conditioned on fidelity, devotedness, patient endurance, though the salvation referred to in Habakkuk is temporal (and, in part, national), while in Hebrews it is an eschatological conception.

The apostle Paul quotes (Rom. I:I7; Gal. 3:I I) only the half-verse under review, in both cases omitting the Septuagint $m y$ (faith) - an erroneous rendering which had probably arisen from the translators' mistaking the Hebrew ending meaning his (constancy) for that meaning $m y$. We naturally ask: (I) To what subject does he apply the text as a whole? (2) What specific meaning does the word $\pi i \sigma \tau \iota s$ bear in his use of it? To these questions we must answer: (I) The text is applied to the subject of justification; and (2) faith bears for Paul the specific meaning of trust in Christ. In Romans ( $1:$ I 7 ) the argument is: I glory in the gospel, for in it is disclosed a way of attaining acceptance with God, which begins and ends in faith - as the Scripture says: The righteous man shall be saved by faith. In Galatians (3:I I) this principle of salvation is set in sharp contrast with the works-principle of the pharisaic theology, thus: Scripture represents Abraham as being justified by faith, not by works. Indeed, salvation by the latter is impossible, for in order to be saved by deeds of meritorious obedience to the law, one must perfectly fulfil the law's demands. Scripture declares that he is still accursed who has left any requirement unfulfilled. But men are powerless perfectly to keep God's law; therefore, as the Old Testament indicates, there is but one practicable way of salvation for sinners - the way of faith, that is, humble selfrenouncing trust in Christ.

We may thus summarize the facts of the case respecting the original meaning and later uses of the text in question: Habakkuk: He who remains constant in his devotion to Jehovah in the midst of the calamities which are approaching, shall be preserved alive. Hebrews: He who patiently endures the present hardships, holding fast his Christian confession, shall attain the blessedness of Messiah's kingdom at his second advent. Paul: $\mathrm{He}$ who renounces all claims and merits of his own and trusts in 
Christ alone shall find justification, acceptance, acquittal from sin and guilt before God.

We conclude: (I) Both New Testament writers entirely neglect the historic occasion and immediate reference of the text. (2) Hebrews cites (from the LXX) the saying in its mistranslated context, and changes the order of clauses for better rhetorical effect. (3) The "shall live" of Habakkuk (meaning "shall be preserved in safety") becomes in Paul "shall be acquitted and forgiven (here and now);" in Hebrews, "shall inherit the messianic kingdom in the coming age." (4) The constancy of the original passage is generically the same in Hebrews (with a Christian application, of course), while in Paul it becomes: personal trust in Christ and life-union with him as the condition of acceptance with God. (5) This example illustrates how the New Testament writers commonly took their citations direct from the LXX, with little regard to verbal accuracy (often quoting from memory), and with as little regard to the immediate reference and connection in the original writing. It was sufficient for them if they discerned some correspondence or connection in ideas or principle between the language of the Old Testament and the particular Christian truths with which they were dealing. In the case before us there was such a connection underlying the differences and variations which we have traced. One general principle runs through all the uses made of the saying in question. It is this: Trustfulness toward God is what he requires; it is the condition of attaining his favor and blessing. 